\title{
Symmetry-based approach to oligostilbenoids: Rapid entry to viniferifuran, shoreaphenol, malibatol $A$, and diptoindonesin $G$
}

\author{
Youngeun Jung ${ }^{\ddagger}$, Dileep Kumar Singh ${ }^{\ddagger}$ and Ikyon Kim ${ }^{*} \S$
}

\author{
Full Research Paper \\ Address: \\ College of Pharmacy and Yonsei Institute of Pharmaceutical \\ Sciences, Yonsei University, 85 Songdogwahak-ro, Yeonsu-gu, \\ Incheon 21983, Republic of Korea \\ Email: \\ Ikyon Kim* - ikyonkim@yonsei.ac.kr \\ * Corresponding author $\ddagger$ Equal contributors \\ $\S$ Tel.: +82 32749 4515; fax: +82 327494105 \\ Keywords: \\ anticancer agent; iodocyclization; natural product; oligostilbenoids; \\ Pd-catalyzed coupling \\ Beilstein J. Org. Chem. 2016, 12, 2689-2693. \\ doi:10.3762/bjoc.12.266 \\ Received: 30 September 2016 \\ Accepted: 25 November 2016 \\ Published: 12 December 2016 \\ Associate Editor: J. Aubé \\ (c) 2016 Jung et al.; licensee Beilstein-Institut. \\ License and terms: see end of document.
} \\ Open Access}

\begin{abstract}
The recognition of the local symmetric image within benzofuran-based natural oligostilbenoids guided us to design a modular synthetic approach to these molecules by utilizing a three-step sequence consisting of Sonogashira coupling, iodocyclization, and Suzuki coupling. During our synthesis, the relative reactivities of ester, aldehyde, and alkoxy groups on the same aryl ring toward the neighboring alkyne in the iodine-mediated cyclization reactions were explored. Starting from the symmetrical 3,5-dimethoxybenzyl alcohol, this route allowed rapid access to 2,3-diarylbenzofuran, a key intermediate to several oligostilbenoid natural products, in good overall yields.
\end{abstract}

\section{Introduction}

Oligostilbenoids constitute a family of natural products with various biological functions (Figure 1). Monomeric stilbene units are interconnected in a number of ways to lead to complex structures [1-3]. Despite a long history of isolation and biological studies of these natural products, relatively little attention has been paid by the synthetic community to chemical synthesis of polyphenolic oligostilbenoids. Most synthetic works on these unique natural products have recently appeared in the literature [4-10].

In connection with our research on benzofurans [11,12], our laboratory has been involved in the synthesis of these benzo- furan-containing natural products for the last several years [1315]. For example, we have reported a concise total synthesis of diptoindonesin $\mathrm{G}$, a potent cytotoxic and immunosuppressant agent $[16,17]$, by using a highly efficient domino cyclodehydration/intramolecular Friedel-Crafts acylation/regioselective demethylation sequence as a key transformation. Very recently, a dual functional role of diptoindonesin $\mathrm{G}$ in modulating $\alpha$ and $\beta$ estrogen receptors (ER) has been discovered, thereby suggesting it as a promising drug lead for the treatment of breast cancer [18]. Our continuing interest in this area led us to design an alternative approach to oligostilbenoids. As shown in Scheme 1, our idea stemmed from recognition of the symmetry 


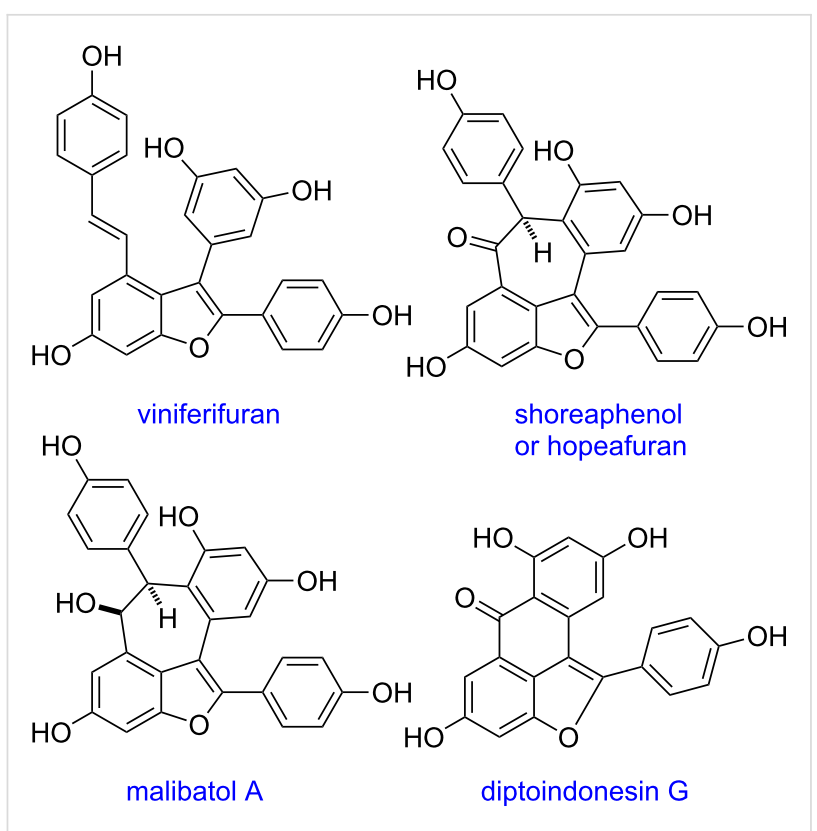

Figure 1: Natural oligostilbenoids.

element [19] of the target molecules. We expected that the key intermediate (inset box of Scheme 1) could be constructed from the monoiodo compounds $\mathbf{1}, \mathbf{2}$, or $\mathbf{3}$ through a sequence involving Sonogashira coupling, iodocyclization [20-26], and Suzuki coupling. As the starting materials $(\mathbf{1}, \mathbf{2}$, and $\mathbf{3})$ were readily available from the corresponding $C 2$ symmetric precursors via monoiodination, we decided to evaluate this route. In particular, we wondered what functional group as a $\mathrm{G}$ moiety would be appropriate for the successful iodine-mediated cyclization. Ester, aldehyde, and alkoxy groups have been used as nucleophiles of iodocyclization for the syntheses of a number of heterocycles, respectively [27-30]. Although Larock's work on relative reactivity of these functional groups toward alkyne during electrophilic cyclization has been reported [31], the study with the substrates having these nucleophiles on the same aromatic ring has not been disclosed, to the best of our knowledge. Here we wish to describe our results.

\section{Results and Discussion}

By following the known procedures, monoiodination of the commercially available methyl 3,5-dimethoxybenzoate, 3,5dimethoxybenzaldehyde, and 3,5-dimethoxybenzyl alcohol under the influence of either $\mathrm{I}_{2}$ /silver trifluoroacetate or $N$-iodosuccinimide afforded 1 [32-34], 2 [35], and 7 [36,37], respectively (Scheme 2). The hydroxy group of 7 was protected as an acetate, providing 3 in $96 \%$ yield. Sonogashira coupling of the resulting iodides $\mathbf{1}, \mathbf{2}$, and $\mathbf{3}$ with alkynylanisole proceeded without any event to give the corresponding alkynes, $\mathbf{4}, \mathbf{5}$, and $\mathbf{6}$, setting the stage for iodocyclization.

When 4 was exposed to $\mathrm{I}_{2}$ and $\mathrm{NaHCO}_{3}$ in $\mathrm{CH}_{2} \mathrm{Cl}_{2}$, two isolable products were obtained (Scheme 3). Surprisingly, 8 was isolated in $32 \%$ yield presumably as a consequence of HI-promoted cyclization even in the presence of excess base. The structure of $\mathbf{8}$ was confirmed by X-ray crystallographic analysis (Figure 2) [38]. The other major product 9, less polar than 8, resulted from 6-endo-dig iodocyclization. Obviously, the ester moiety in $\mathbf{4}$ was competitively involved in the iodinemediated electrophilic cyclization. Only a trace amount of $\mathbf{1 0}$ was isolated upon subjection of $\mathbf{5}$ to the same reaction conditions. We suspected that the aldehyde in $\mathbf{5}$ also acted as a nucleophile to furnish unstable oxocarbenium species (inset box of Scheme 3) as a major product which decomposed eventually. On the other hand, 6 was successfully converted to the desired 3-iodobenzofuran 11 in good yield. These results led us con-<smiles>COc1ccc(C#Cc2c(Cl)cc(OC)cc2OCCOC(C)=O)cc1</smiles>

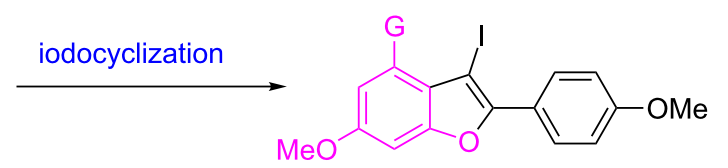

$$
\begin{aligned}
& 4 \mathrm{G}=\mathrm{CO}_{2} \mathrm{Me} \\
& 5 \mathrm{G}=\mathrm{CHO} \\
& 6 \mathrm{G}=\mathrm{CH}_{2} \mathrm{OAc}
\end{aligned}
$$

Suzuki coupling

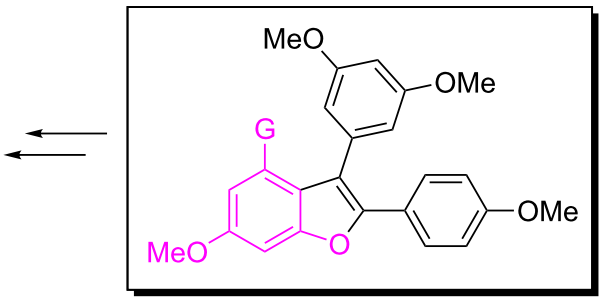




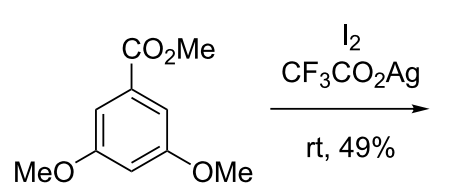<smiles>COc1cc(OC)c(I)c(C(C)=O)c1</smiles>

1<smiles>COc1cc(C=O)cc(OC)c1</smiles><smiles>COc1cc(C=O)c(I)c(OC)c1</smiles><smiles>COc1cc(CO)cc(OC)c1</smiles>

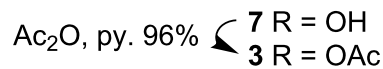

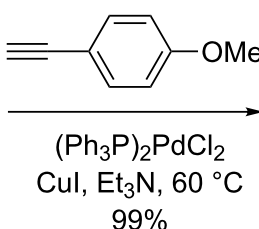

$99 \%$<smiles>COc1ccc(C#Cc2c(OC)cc(OC)cc2C(C)=O)cc1</smiles><smiles>C#Cc1ccc(OC)cc1</smiles>
$96 \%$<smiles>COc1ccc(C#Cc2c(C=O)cc(OC)cc2OC)cc1</smiles>

5

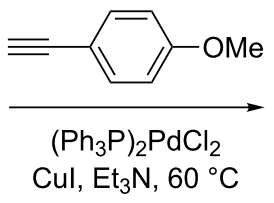

$80 \%$<smiles>COc1ccc(C#Cc2c(COC(C)=O)cc(OC)cc2OC)cc1</smiles>

Scheme 2: Synthesis of $\mathbf{4 , 5}$, and 6 .

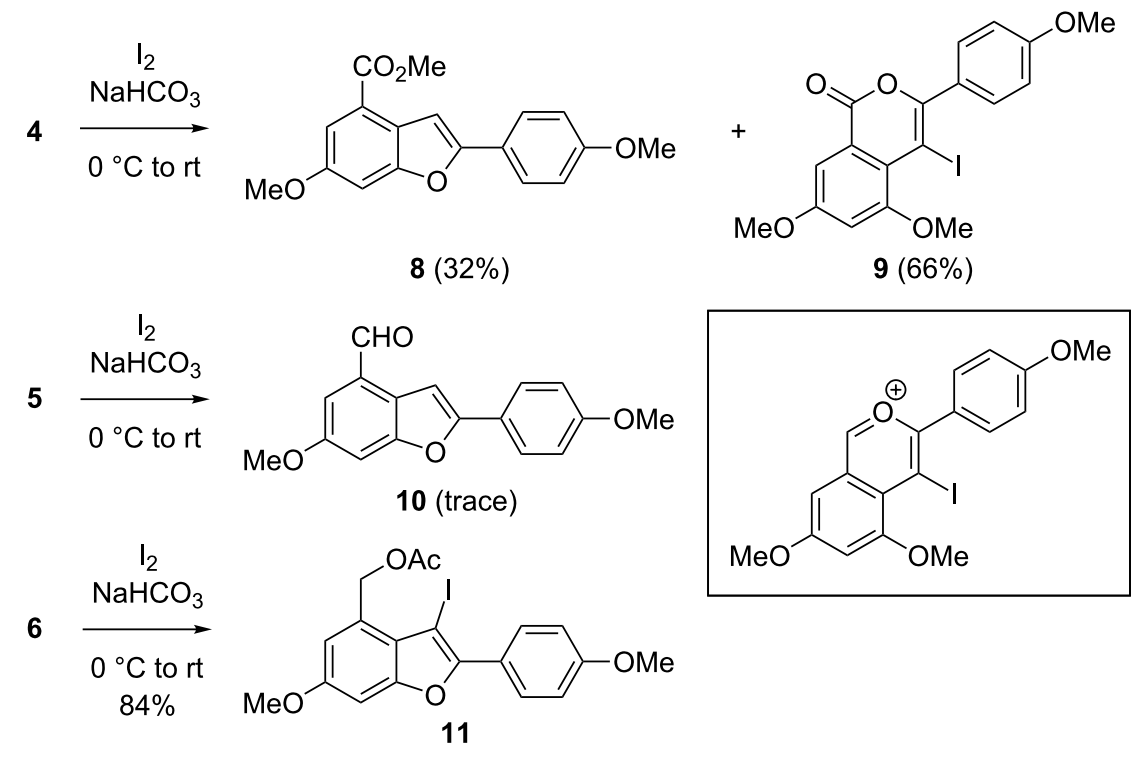

Scheme 3: lodocyclization.

clude that either ester or aldehyde groups perform as better nucleophiles than an alkoxy group in the iodocyclization.

Having secured gram quantities of 3-iodobenzofuran 11 in hand, our next task was to elaborate the conversion of $\mathbf{1 1}$ to 2,3diarylbenzofurans (Scheme 4). To this end, 11 was first transformed to aldehyde $\mathbf{1 3}$ via $\mathbf{1 2}$ through a two-step sequence consisting of deacetylation and Dess-Martin oxidation [39]. To our delight, the subsequent Suzuki cross-coupling of 13 with 3,5-dimethoxyphenylboronic acid under the reaction conditions analogous as described before [26] proceeded well and furnished 14 in $88 \%$ yield. This intermediate was used for our previous syntheses of permethylated analogues of viniferifuran, malibatiol A, and shoreaphenol [13]. Under similar reaction conditions, several other arylboronic acids reacted with $\mathbf{1 3}$ to give the corresponding products in good yields, demonstrating 


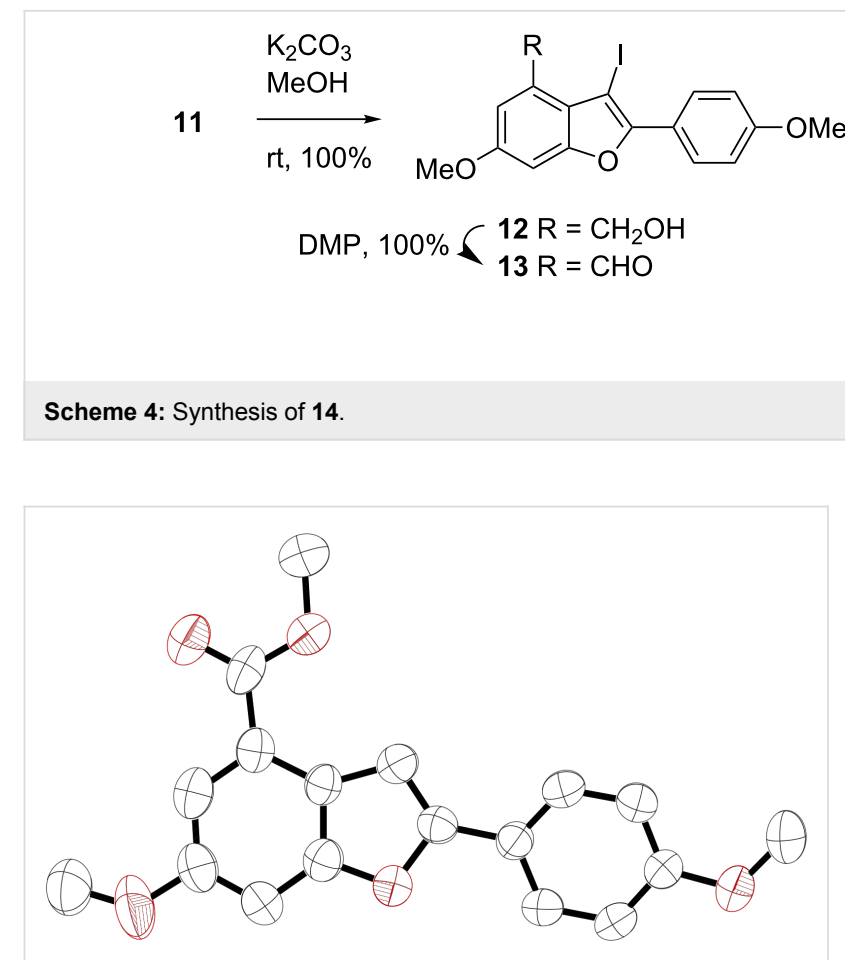

Figure 2: Crystal structure of $\mathbf{8}$.

the general usefulness of this route for the synthesis of a range of structural analogues at a late stage.

The direct Friedel-Crafts type intramolecular cyclization of $\mathbf{1 4}$ induced by $\mathrm{BCl}_{3}$ was attempted but a complex mixture was observed. Thus, oxidation of the aldehyde in $\mathbf{1 4}$ to carboxylic acid was carried out. Pinnick oxidation [40-42] of 14 went smoothly to give $\mathbf{1 8}$, an intermediate previously employed for the synthesis of diptoindonesin G (Scheme 5) [43,44].

\section{Conclusion}

In summary, we have established a highly scalable and flexible synthetic route to several benzofuran-containing oligostilbenoid natural products by relying on a symmetry-breaking strategy from 3,5-dimethoxybenzyl alcohol. The relative reactivity of ester, aldehyde, and methoxy moieties toward the neighboring alkyne in the course of iodocyclization was investigated, revealing that neither ester nor aldehyde was compatible under these conditions to reach the desired product. The versatile key intermediates for the syntheses of several oligostilbenoids such as viniferifuran, shoreaphenol, malibatol $\mathrm{A}$, and diptoindonesin $\mathrm{G}$ were rapidly accessed in a highly efficient manner, allowing for large-scale preparations of the target natural products as well as unnatural analogues.

\section{Supporting Information}

\section{Supporting Information File 1}

Experimental procedures, compound characterization data, and ${ }^{1} \mathrm{H}$ and ${ }^{13} \mathrm{C}$ NMR spectra of synthesized compounds.

[http://www.beilstein-journals.org/bjoc/content/ supplementary/1860-5397-12-266-S1.pdf]

\section{Supporting Information File 2}

Chemical information file of compound $\mathbf{8}$.

[http://www.beilstein-journals.org/bjoc/content/ supplementary/1860-5397-12-266-S2.cif]

\section{Acknowledgements}

This work was supported by the National Research Foundation of Korea (NRF) grant funded by the Korea government (MSIP) (2014R1A2A1A11050491). This work was also supported in part by the Yonsei Research Fund of 2015 (project no.: 201512-0215).<smiles>COc1ccc(-c2oc3cc(OC)cc(C(=O)O)c3c2-c2cc(OC)cc(OC)c2)cc1</smiles> 


\section{References}

1. Quideau, S.; Deffieux, D.; Douat-Casassus, C.; Pouységu, L. Angew. Chem., Int. Ed. 2011, 50, 586. doi:10.1002/anie.201000044

2. Keyler, M. H.; Matsuura, B. S.; Stephenson, C. R. J. Chem. Rev. 2015, 115, 8976. doi:10.1021/cr500689b

3. Wang, X.-F.; Yao, C.-S. J. Asian Nat. Prod. Res. 2016, 18, 376. doi:10.1080/10286020.2015.1094464

4. Li, W.; Li, H.; Li, Y.; Hou, Z. Angew. Chem., Int. Ed. 2006, 45, 7609. doi:10.1002/anie.200603097

5. Snyder, S. A.; Breazzano, S. P.; Ross, A. G.; Lin, Y.; Zografos, A. L. J. Am. Chem. Soc. 2009, 131, 1753. doi:10.1021/ja806183r

6. Nicolaou, K. C.; Wu, T. R.; Kang, Q.; Chen, D. Y.-K. Angew. Chem., Int. Ed. 2009, 48, 3440. doi:10.1002/anie.200900438

7. Jeffrey, J. L.; Sarpong, R. Org. Lett. 2009, 11, 5450. doi:10.1021/ol902141z

8. Snyder, S. A.; Gollner, A.; Chiriac, M. I. Nature 2011, 474, 461. doi:10.1038/nature10197

9. Jepsen, T. H.; Thomas, S. B.; Lin, Y.; Stathakis, C. I.; de Miguel, I.; Snyder, S. A. Angew. Chem., Int. Ed. 2014, 53, 6747. doi:10.1002/anie.201402858

10. Matsuura, B. S.; Keylor, M. H.; Li, B.; Lin, Y.; Allison, S.; Pratt, D. A.; Stephenson, C. R. J. Angew. Chem., Int. Ed. 2015, 54, 3754. doi:10.1002/anie.201409773

11. Kim, I.; Lee, S.-H.; Lee, S. Tetrahedron Lett. 2008, 49, 6579. doi:10.1016/j.tetlet.2008.09.034

12. Kim, I.; Kim, K.; Choi, J. J. Org. Chem. 2009, 74, 8492. doi:10.1021/jo901937u

13. Kim, I.; Choi, J. Org. Biomol. Chem. 2009, 7, 2788. doi:10.1039/b901911a

14. Kim, K.; Kim, I. Org. Lett. 2010, 12, 5314. doi:10.1021/ol102322g

15. Lee, J. H.; Kim, M.; Kim, I. J. Org. Chem. 2014, 79, 6153. doi:10.1021/jo500885w

16. Juliawaty, L. D.; Sahidin, H.; akim, E. H.; Achmad, S. A.; Syah, Y. M.; Latip, J.; Said, I. M. Nat. Prod. Commun. 2009, 4, 947.

17. Ge, H. M.; Yang, W. H.; Shen, Y.; Jiang, N.; Guo, Z. K.; Luo, Q.; Xu, Q.; Ma, J.; Tan, R. X. Chem. - Eur. J. 2010, 16, 6338 doi:10.1002/chem.201000230

18. Zhao, J.; Wang, L.; James, T.; Jung, Y.; Kim, I.; Tan, R.; Hoffmann, F. M.; Xu, W. Chem. Biol. 2015, 22, 1608. doi:10.1016/j.chembiol.2015.10.011

19. Ho, T.-L. Symmetry: A Basis for Synthesis Design; John Wiley \& Sons, Inc.: New York, 1995.

20. Kim, I.; Choi, J.; Won, H. K.; Lee, G. H. Tetrahedron Lett. 2007, 48, 6863. doi:10.1016/j.tetlet.2007.07.180

21. Kim, I.; Won, H. K.; Choi, J.; Lee, G. H. Tetrahedron 2007, 63, 12954. doi:10.1016/j.tet.2007.10.037

22. Kim, I.; Kim, S. G.; Kim, J. Y.; Lee, G. H. Tetrahedron Lett. 2007, 48, 8976. doi:10.1016/j.tetlet.2007.10.101

23. Choi, J.; Lee, G. H.; Kim, I. Synlett 2008, 1243. doi:10.1055/s-2008-1072721

24. Kim, K.; Kim, I. J. Comb. Chem. 2010, 12, 379. doi:10.1021/cc100015k

25. Jung, Y.; Kim, I. Tetrahedron 2012, 68, 8198 doi:10.1016/j.tet.2012.07.068

26. Jung, Y.; Kim, I. Asian J. Org. Chem. 2016, 5, 147. doi:10.1002/ajoc.201500423

27. Biagetti, M.; Bellina, F.; Carpita, A.; Stabile, P.; Rossi, R. Tetrahedron 2002, 58, 5023. doi:10.1016/S0040-4020(02)00469-6

28. Yao, T.; Larock, R. C. J. Org. Chem. 2003, 68, 5936. doi:10.1021/jo034308v
29. Yue, D.; Yao, T.; Larock, R. C. J. Org. Chem. 2005, 70, 10292 doi:10.1021/jo051299c

30. Verma, A. K.; Aggarwal, T.; Rustagi, V.; Larock, R. C. Chem. Commun. 2010, 46, 4064. doi:10.1039/b927185f

31. Mehta, S.; Waldo, J. P.; Larock, R. C. J. Org. Chem. 2009, 74, 1141. doi:10.1021/jo802196r

32. Manzo, E.; Ciavatta, M. L. Tetrahedron 2012, 68, 4107. doi:10.1016/j.tet.2012.04.010

33. Leermann, T.; Broutin, P.-E.; Leroux, F. R.; Colobert, F. Org. Biomol. Chem. 2012, 10, 4095. doi:10.1039/c2ob25373a

34. Ehrlich, M.; Carell, T. Eur. J. Org. Chem. 2013, 77. doi:10.1002/ejoc.201201256

35. Harrowven, D. C.; Nunn, M. I. T.; Fenwick, D. R. Tetrahedron Lett. 2002, 43, 7345. doi:10.1016/S0040-4039(02)01720-3

36. Swindell, C. S.; Fan, W. J. Org. Chem. 1996, 61, 1109. doi:10.1021/jo9519367

37. Murata, C.; Ogura, T.; Narita, S.; Kondo, A. P.; Iwasaki, N.; Saito, T.; Usuki, T. Bioorg. Med. Chem. Lett. 2016, 26, 1428. doi:10.1016/j.bmcl.2016.01.067

38. CCDC 1503940 contains the supplementary crystallographic data for compound 8 . These data can be obtained free of charge from The Cambridge Crystallographic Data Centre via http://www.ccdc.cam.ac.uk/data_request/cif.

39. Dess, D. B.; Martin, J. C. J. Org. Chem. 1983, 48, 4155. doi:10.1021/jo00170a070

40. Lindgren, B. O.; Nilsson, T. Acta Chem. Scand. 1973, 27, 888. doi:10.3891/acta.chem.scand.27-0888

41. Kraus, G. A.; Taschner, M. J. J. Org. Chem. 1980, 45, 1175. doi:10.1021/jo01294a058

42. Bal, B. S.; Childers, W. E., Jr.; Pinnick, H. W. Tetrahedron 1981, 37, 2091. doi:10.1016/S0040-4020(01)97963-3

43. Conversion of 18 to diptoindonesin $\mathrm{G}$ was reported via intramolecular Friedel-Crafts acylation/global demethylation in $72 \%$ overall yield. See ref. [14].

44. Liu, J.-t.; Do, T. J.; Simmons, C. J.; Lynch, J. C.; Gu, W.; Ma, Z.-X.; Xu, W.; Tang, W. Org. Biomol. Chem. 2016, 14, 8927. doi:10.1039/C6OB01657J

See for another total synthesis of diptoindonesin $\mathrm{G}$ and its analogues which was published during the preparation of this article.

\section{License and Terms}

This is an Open Access article under the terms of the Creative Commons Attribution License (http://creativecommons.org/licenses/by/4.0), which permits unrestricted use, distribution, and reproduction in any medium, provided the original work is properly cited.

The license is subject to the Beilstein Journal of Organic Chemistry terms and conditions: (http://www.beilstein-journals.org/bjoc)

The definitive version of this article is the electronic one which can be found at: doi:10.3762/bjoc. 12.266 